\title{
The Effect of Service Quality, Halal Tourism on Brand Image of Hotels in Padang
}

\author{
Dede Irama ${ }^{1}$, Abror Abror ${ }^{2 *}$ \\ ${ }_{1}^{1}$ Universitas Negeri Padang, Padang, Indonesia, $\square$ dedeirama04@gmail.com \\ ${ }^{2}$ Universitas Negeri Padang, Padang, Indonesia, $₫$ abror094@gmail.com; abror094@fe.unp.ac.id \\ * Corresponding author
}

\begin{abstract}
Halal tourism is an emerging issue currently due to the increase of the Muslim tourists around the world. This research aims to investigate the relationship between halal tourism (Islamic facilities, Halal, general Islamic morality, and alcohol and gambling free) and service quality towards the hotel brand image in Padang. The population in this study were tourists who visited the city of Padang and stayed at the hotel. This study used 75 respondents as the samples. The analysis was carried out by using SPSS software. The findings show that halal tourism has a significant influence on brand image of hotels in Padang. Service quality is also a significant antecedent of Brand image. Furthermore, some limitations and further studies are discussed.
\end{abstract}

Keywords: Halal Tourism; Service Quality; Brand Image; West Sumatra

\section{Introduction}

West Sumatra is one of the province in Indonesia who won the award of "World's Best Halal Destination" at the 2016 World Halal Tourism Award (WHTA) competition in Abu Dhabi, Emirate Arab Union (UAE) in December 2016. It is estimated that the Muslim population is $30 \%$ of the world in 2025 (Ukessays, 2014). The increasing number of tourist visit has been reached in to $1.5 \%$ a year in West Sumatra based on the data of the world's Muslim population. Wardi et al. (2018) said that with the population of West Sumatra as halal tourism was warmly discussed. This makes West Sumatra especially Padang need to improve itself in offering Islamic tourism. Halal is important for Muslim tourists. Iniesta-Bonillo et al. (2016), halal tourism provides satisfaction for Muslim tourists. Battour and Ismail (2016) also stated that halal tourism provided facilities for Muslims to carry out worship while traveling. Dealing with this, it is named as halal tourism. According to a book entitled 'The Lawful and the Prohibited in Islam, written by Sheikh Yusuf al-Qaradawi, an Islamic scholar and chair of the International Muslim Scholars Association, the term Halal is defined as "what is permitted, and what is permitted by the lawgiver, Allah" (Al-Qaradawi, 2013; p. XXV). From an Islamic perspective, halal is defined as Al-Qaradawi refers to any practice or activity that is 'permitted' according to Islamic teachings.

Increasing tourist arrivals to West Sumatra have an impact on the high demand for hotels which are a place of rest for tourists (Lado-Sestayo, Fernández-Castro 2018). The hospitality industry is a competitive market which is one of hotel management indicator such as service quality hotels, Islamic-based hotel services (halal tourism) that create a good hotel brand image for customers.

Contrast from previous research, researcher discussed two things. The first, there is a theoretic contribution relationship between halal tourism and the hotel brand image. The second is the relationship between service quality and the hotel brand image. Indeed, this research can give recommendation to hotel management in enhancing the hotel brand image through service quality and halal tourism.

According to Surachman (2008) brand image is a part of a brand that can be recognized but cannot be pronounced, such as symbols, letter designs or special colors, or customer perceptions of a product or service represented by the brand. Kotler and Keller (2012) stated that customers might have different responses to the company's image or brand. While Kotlet and Keller,(2012) brands are a set of brand associations that are formed and attached to the minds of consumers. Consumers who are accustomed to using certain brands tend to have consistency with brand image. An effective image will have effect on three things. The first, strengthening the product character and the proposed 
value. Second, convey the character in a different way so that it is not confused with the competitor's character. Third, giving emotional strength that is more than just a mental image.

Consumers often base purchasing decisions on a company's Brand image (Kim \& Kim, 2005). A high brand image can give consumers confidence in paying premium prices (Cretu \& Brodie, 2007). Muslims in doing every activity are always related to their religion, therefore the concept of halal traditions must be in line with the rules of Islamic religion Unique brand image distinguishes the value of brands and brands so that they can put the brand in a certain position in the minds of consumers that contribute to increasing brand equity potential. Brand image has a relationship with halal tourism and service quality which will be discussed later.

Service quality is the customer's assessment and it is the main appliance of the hospitality business industry. The hospitality industry satisfies visitors and increase goal loyalty. Service quality is an evaluation of tourists for the expected service. If the industry fails to provide quality services, customers turn to other goals (Sparks \& Westgate, 2002). The main factors that influence the quality of service are the customer's expectation of service and customer's perception of service. If the perception of service is convenient with what the customers expected, then the quality of the service is good and positively recommended. If the service exceeds more than what the customers expect, then the quality of service is the ideal service quality. Conversely, if the service is worse than what the customer expects, then the quality of service is not good.

As Muslim tourists increased, the need for halal tourism also increased. According to Jafari and Scott (2014) Halal tourism is a motivation from Muslim tourists who tend to fulfill muslim customers Sharia law requirements who are sensitive to products and services that appropriate to Sharia (Jafari \& Scott, 2014).Halal is a reference for Muslims to do something that can be done and not done based on the recitation of the Koran and hadith which is the main source of law and guidance of life. In Islam, traveling activities are considered as 'worship and da'wah' (Laderlah et al., 2011). Tourism can be a 'worship' if the purpose of the trip is because of Allah. "Da'wah" means activities that call for, invite and call people to believe and obey Allah. Islamic tourism has many benefits and helps tourists to reduce flatness, anxiety, tension and recalibrate their minds. Islamic tourists can obtain knowledge and information by thinking about the beauty of Allah's creation (Al-Hamarneh \& Steiner, 2004)

Effect of Halal tourism on brand image

There is often a misperception in mentioning Islamic branding (Battour et al., 2014). This happened because of a misunderstanding of the meaning of halal itself. There are differences between Islamic brands and conventional brands of Islamic brands about giving the truth and giving worship to sellers and buyers, selling not only life but also worship (Alserhan, 2010). It was found that halal had a significant effect on the brand of a product and included sharia products and services. (Battour et al., 2014). Halal tourism indicators used in this study are based on Wardi, abror and trinanda, 2018 namely worship facilities, Halal, halal morality, free alcoholic beverages, and gambling. Thus, halal tourism affects the hotel brand image. The hypothesis is:

H1. Halal tourism has a significant impact on the hotel brand image

Service quality is the overall description of the characteristics and characteristics of a product or service, based on their ability to express satisfaction or needs indirectly (Kozak, 2003). When a customer feels the service performance is the same as or higher than his expectations, he will be satisfied and remember that as a good product and service provided has a good service quality and brand image. Some studies suggest that the perception of service quality in a place has a positive influence on affective brand image in a place that feels good, comfortable and good ((Ramanthan and Ramanthan, 2013). Service quality has an effect on destination image both affective image and cognitive image and will ultimately have a positive influence on one's behavior to make decisions (Lee, et al., 2018). The hypothesis proposed is:

H2. Service quality has a significant relationship to the hotel brand image 
Table 1 Research Variables

\begin{tabular}{|c|c|c|c|}
\hline Num. & Variabel & Indicator & Source \\
\hline \multirow{12}{*}{1} & \multirow{12}{*}{ Brand Image } & Comfortable hotel atmosphere & \multirow{12}{*}{ Liu eat al, 2017} \\
\hline & & This hotel offers high quality services & \\
\hline & & This hotel is luxurious & \\
\hline & & This hotel is expensive and lawful & \\
\hline & & This hotel is a free from alcoholic beverage & \\
\hline & & $\begin{array}{l}\text { This hotel makes me feel special brand image has a positive } \\
\text { impact on hotel guests to stay in hotels }\end{array}$ & \\
\hline & & Friendly hotel service & \\
\hline & & This hotel is large and spacious & \\
\hline & & This hotel gives a religious feeling & \\
\hline & & $\begin{array}{l}\text { Hotel provide services beyond my expectations of halal food and } \\
\text { non halal food }\end{array}$ & \\
\hline & & This hotel has a long history & \\
\hline & & I feel a different feeling in this hotel than other hotels & \\
\hline \multirow{11}{*}{2} & \multirow{11}{*}{ Halal Tourism } & I can easily find prayer rooms in hotels & \multirow{11}{*}{$\begin{array}{c}\text { Wardi, abror dan } \\
\text { trinanda,2018; Abror et.al., } \\
2019\end{array}$} \\
\hline & & The hotel provides supporting tools for worship & \\
\hline & & I can hear the call to pray at prayer time & \\
\hline & & I can easily find halal food & \\
\hline & & $\begin{array}{l}\text { I can find a separation of kitchens that cook halal food with those } \\
\text { that don't }\end{array}$ & \\
\hline & & Eliminate pronography channels on hotel channels / television & \\
\hline & & I can find a ban on prostitution in hotels & \\
\hline & & $\begin{array}{l}\text { There is a prohibition to display excessive acts of affection in } \\
\text { public }\end{array}$ & \\
\hline & & I saw a censorship of an adult scene on the film that was aired & \\
\hline & & $\begin{array}{l}\text { There is a prohibition on drinking alcoholic drinks in public } \\
\text { places }\end{array}$ & \\
\hline & & Prohibition of gambling activities in public places & \\
\hline \multirow{15}{*}{3} & \multirow{15}{*}{ Service Quality } & I saw a lot of plants around the hotel & \multirow{15}{*}{ Chen et all, 2013} \\
\hline & & $\begin{array}{l}\text { Packaging materials, napkins and hotel menus use materials that } \\
\text { are environmentally friendly }\end{array}$ & \\
\hline & & $\begin{array}{l}\text { Tableware used in eco-friendly hotels that are not classified as } \\
\text { disposable }\end{array}$ & \\
\hline & & $\begin{array}{l}\text { The hotel conforms to the AC temperature of the general public's } \\
\text { needs and government regulations }\end{array}$ & \\
\hline & & The hotel has good air circulation and natural lighting & \\
\hline & & $\begin{array}{l}\text { The toiletries used by hotels are economical in terms of water } \\
\text { supply }\end{array}$ & \\
\hline & & Hotels provide halal food and services & \\
\hline & & Food and services provided by the hotel meet my needs & \\
\hline & & $\begin{array}{l}\text { The food provided by the hotel is consistent with the promised } \\
\text { menu }\end{array}$ & \\
\hline & & Hotels are responsive in providing needed services & \\
\hline & & The hotel provides the best to meet customers' special needs & \\
\hline & & $\begin{array}{l}\text { Customer needs for services and food can be understood by the } \\
\text { hotel well }\end{array}$ & \\
\hline & & Hotel employees can answer questions about the hotel & \\
\hline & & Hotels can ensure the best halal food & \\
\hline & & $\begin{array}{l}\text { Employees have professional knowledge and good and } \\
\text { standardized education }\end{array}$ & \\
\hline
\end{tabular}


Table Cont...

\begin{tabular}{l} 
Customer needs can be met by hotel employees \\
Every time meeting with hotel staff customers always shows \\
concern for customers \\
\hline $\begin{array}{l}\text { Employees oriented to the service environment and care about } \\
\text { customer needs }\end{array}$ \\
\hline The hotel notifies environmental ideas and policies \\
\hline Food and services offered by hotels can be suitable for halal \\
environmental protection \\
\hline Compared to other hotels, this hotel has more halal food \\
available \\
\hline Compared to other hotels, there are no alcoholic drinks in this \\
hotel \\
\hline Compared to other hotels, this hotel has a ban on pornography \\
and pornographic action \\
\hline Food and drinks offered by the hotel are delicious and delicious \\
\hline The hotel offers delicious and halal Padang food \\
\hline Design food menus according to the hotel \\
\hline The food and drinks offered by the hotel are natural \\
\hline $\begin{array}{l}\text { Hotels provide a measure of nutritional value, calories, and halal } \\
\text { food }\end{array}$
\end{tabular}

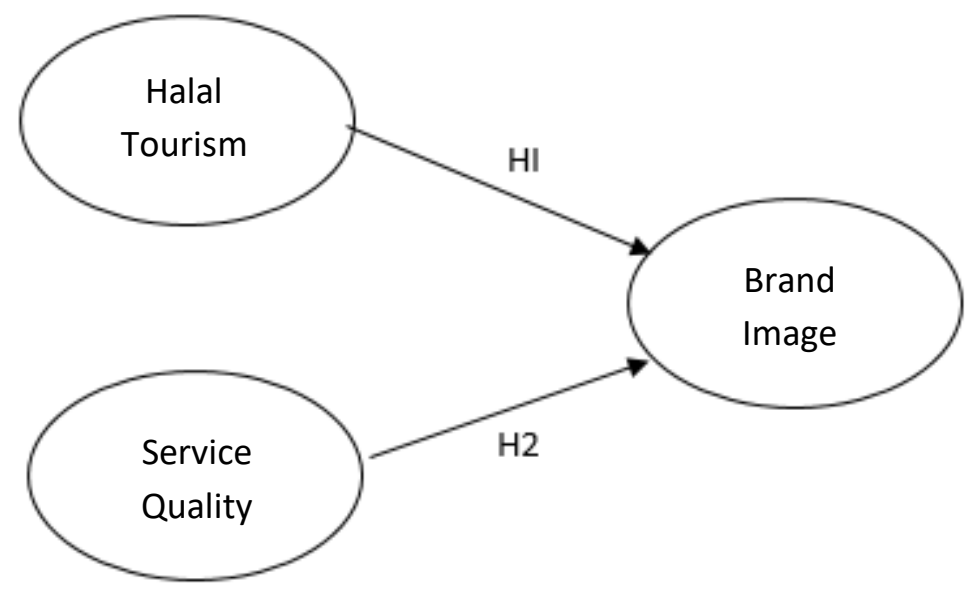

Figure 1 Research Model

\section{Methods}

This research was conducted in West Sumatra. West Sumatra is the best place for halal tourist destinations in 2016 as the World's Best Halal Travel Destination by ITW Abu Dhabi. The type of research used is to explain the position of the variable being examined, and the relationship between one variable and other variables, and test the hypothesis. The isolation of research is all the people and tourists who came to the West Sumatra. Determination of samples using Random Sampling is said to be simple (simple) because taking members of the sample from the population is done randomly without considering the strata that exist in that population (Sugiyono, 2012: 121). The feasible sample size in the study was between 30 and 500. The sample used in this study was 75 people. The technique used in sampling is incidental sampling. is a sampling technique based on coincidence, that is, anyone who randomly encounters a researcher and is suitable as a data source.

Analysis of the data used in this study is multiple linear regression analysis is a linear relationship between two or more independent variables $(\mathrm{X} 1, \mathrm{X} 2, \ldots \mathrm{Xn})$ with the dependent variable $(\mathrm{Y})$. The 
analysis aims to determine the direction of the relationship between the independent variable and the dependent variable whether each independent variable is positively or negatively related and to predict the value of the dependent variable. The data used is interval or ratio.

The coefficient $(X 1, X 2, \ldots X n)$ shows how much the percentage variation of the independent variables used in the model is able to explain the variation of the dependent variable. R2 is equal to 0 , indicating that the independent variable used in the model does not explain the smallest variation in the dependent variable. Conversely R2 equals 1 , then the variation in the independent variables used in the model explains $100 \%$ variation in the dependent variable. The level of significance uses a $=5 \%$ ( $5 \%$ or 0.05 significance is a standard measure that is often used in research).

Testing criteria:

Ho is accepted if $\mathrm{F}$ is calculated as $<\mathrm{F}$ table

Ho is rejected if $\mathrm{F}$ count $>\mathrm{F}$ table

\section{Results and Discussion}

Based on gender, most of the tourists are female (58.7\%) and men $(41.3 \%)$ a year. The highest age is $30-50$ years $(44 \%), 17-30$ years $(32 \%),<17$ years (13.7). In addition, in terms of undergraduate education, the highest position is $(64 \%)$ and high school $(26 \%)$. The study has validity, reliability, outliers, normality, multicollinearity, and homogeneity of variance. Therefore, after all the tests, we only used 75 responses that could be used from the 90 questionnaires collected

Table 2 Construct validity and reliability

\begin{tabular}{|c|c|c|c|c|}
\hline Constructs & Items & Mean & Std. dev & $\begin{array}{l}\text { Cronbach's Alpha if } \\
\text { Item Deleted }\end{array}$ \\
\hline \multirow{12}{*}{ Brand Image } & BI.1 & 3,52 & 0,723 & 0,680 \\
\hline & BI.2 & 3,77 & 0,815 & 0,706 \\
\hline & BI.3 & 3,23 & 1,122 & 0,710 \\
\hline & BI.4 & 3,31 & 0,87 & 0,695 \\
\hline & BI.5 & 3,35 & 0,908 & 0,679 \\
\hline & BI.6 & 3,67 & 0,759 & 0,705 \\
\hline & BI.7 & 3,73 & 0,777 & 0,692 \\
\hline & BI.8 & 3,19 & 1,159 & 0,712 \\
\hline & BI.9 & 3,19 & 1,087 & 0,692 \\
\hline & BI.10 & 3,40 & 0,822 & 0,712 \\
\hline & BI.11 & 3,75 & 0,887 & 0,707 \\
\hline & BI.12 & 3,52 & 0,76 & 0,688 \\
\hline \multirow{11}{*}{ Halal Tourism } & HI.1 & 3,20 & 1,078 & 0,631 \\
\hline & HI.2 & 3,41 & 0,917 & 0,669 \\
\hline & HI.3 & 3,55 & 0,827 & 0,657 \\
\hline & HI.4 & 3,67 & 0,759 & 0,649 \\
\hline & HI.5 & 3,76 & 0,786 & 0,643 \\
\hline & HI.6 & 3,36 & 1,074 & 0,65 \\
\hline & HI.7 & 3,44 & 1,03 & 0,653 \\
\hline & HI.8 & 3,71 & 0,955 & 0,74 \\
\hline & HI.9 & 3,67 & 0,759 & 0,633 \\
\hline & HI.10 & 3,44 & 0,889 & 0,657 \\
\hline & HI.11 & 3,31 & 0,822 & 0,675 \\
\hline
\end{tabular}


Table 3 Construct validity and reliability

\begin{tabular}{|c|c|c|c|c|}
\hline \multirow[b]{2}{*}{ Constructs } & \multirow[b]{2}{*}{ Items } & \multirow[b]{2}{*}{ Mean } & \multicolumn{2}{|r|}{ Cronbach's } \\
\hline & & & Std. dev & $\begin{array}{l}\text { Alpha if Item } \\
\text { Deleted }\end{array}$ \\
\hline & SQ.1 & 3,44 & 0,826 & 0,943 \\
\hline & SQ.2 & 3,52 & 0,795 & 0,943 \\
\hline & SQ.3 & 3,76 & 0,836 & 0,940 \\
\hline & SQ.4 & 3,24 & 1,113 & 0,938 \\
\hline & SQ.5 & 3,67 & 1,044 & 0,941 \\
\hline & SQ.6 & 3,72 & 0,763 & 0,942 \\
\hline & SQ.7 & 3,71 & 0,897 & 0,940 \\
\hline & SQ.8 & 3,41 & 0,917 & 0,940 \\
\hline & SQ.9 & 3,33 & 0,827 & 0,940 \\
\hline & SQ.10 & 3,43 & 0,888 & 0,940 \\
\hline & SQ.11 & 3,65 & 0,780 & 0,943 \\
\hline & SQ.12 & 3,79 & 0,810 & 0,940 \\
\hline & SQ.13 & 3,25 & 1,175 & 0,939 \\
\hline & SQ.14 & 3,23 & 1,110 & 0,938 \\
\hline & SQ.15 & 3,19 & 1,193 & 0,938 \\
\hline & SQ.16 & 3,21 & 1,154 & 0,938 \\
\hline & SQ.17 & 3,27 & 1,155 & 0,938 \\
\hline & SQ.18 & 3,73 & 0,741 & 0,942 \\
\hline & SQ.19 & 3,76 & 0,867 & 0,941 \\
\hline & SQ.20 & 3,39 & 0,914 & 0,940 \\
\hline & SQ.21 & 2,40 & 0,930 & 0,948 \\
\hline & SQ.22 & 3,73 & 0,759 & 0,942 \\
\hline & SQ.23 & 3,77 & 0,831 & 0,940 \\
\hline & SQ.24 & 3,45 & 0,934 & 0,941 \\
\hline & SQ.25 & 3,35 & 0,830 & 0,940 \\
\hline & SQ.26 & 3,67 & 0,759 & 0,942 \\
\hline & SQ.27 & 3,72 & 0,879 & 0,940 \\
\hline & SQ.28 & 3,19 & 1,111 & 0,938 \\
\hline
\end{tabular}

Source: Secondary Processing Data 2019

Based on the results of data processing, Cronbach's Alpha if the Deleted Item is above 0.3 means that the validity requirements have been met because the $r$ value calculated is greater than 0.3 . It is known that: halal tourism indicators are four with 11 questions in the questionnaire. The calculated value is greater than 0.3 . Service quality indicators are 7 with 28 questions in the questionnaire obtained $\mathrm{r}$ count greater than 0.3 . The brand image indicator is 7 with 12 questions in the questionnaire obtained $\mathrm{r}$ count greater than 0.3 .

Table 4 Coefficients

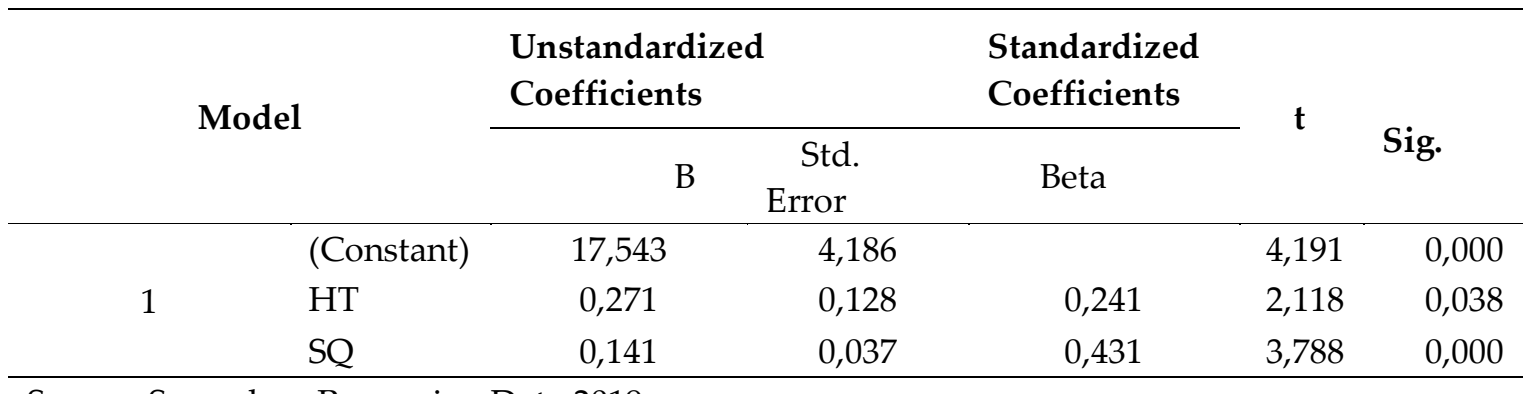

Source: Secondary Processing Data 2019 
Standart value $\mathrm{T}$ table $\mathrm{df}=\mathrm{n}-\mathrm{k}=75-3=72=1,99300$. Based on the data of the findings above can be obtained $y=3,716+0,783 x_{1}+0,215 x_{2}+e$. Based on the results of the data processing, Cronbach's Alpha if Item Deleted is above 0.3 means that the validity requirements have been met because the calculated $r$ value is greater than 0.3. It is known that: halal tourism indicators are four with 11 questions in questionnaire. Obtained $r$ count value greater than 0.3 . The indicator of service quality is 7 with 28 questions in questionnaire obtained $r$ count greater than 0.3. Brand image indicator is 7 with 12 questions in questionnaire obtained $\mathrm{r}$ count greater than 0.3 .

Table 5 Anova

\begin{tabular}{ccccccc}
\hline \multirow{2}{*}{ Model } & & $\begin{array}{c}\text { Sum of } \\
\text { Squares }\end{array}$ & df & $\begin{array}{c}\text { Mean } \\
\text { Square }\end{array}$ & F & \multirow{2}{*}{ Sig. } \\
\hline \multirow{4}{*}{1} & Regression & 761,567 & 2 & 380,784 & 20,396 & \multirow{2}{*}{, $000^{\mathrm{b}}$} \\
& Residual & 1344,22 & 72 & 18,67 & & \\
& Total & 2105,787 & 74 & & & \\
\hline
\end{tabular}

Source: Secondary Processing Data 2019

Evaluation of realiability is seen based on the Cronbach's Alpha table. Cronbach's Alpha value is for each variable. The recommended value is 0.6 according to Arikonto (2002). Based on the results of data processing, it was found that Cronbach's Alpha values above 0,6 found Cronbach's Alpha values of $x_{1}=0,804, x_{2}=0,904$ dan $Y=0,895$. All Cronbach's Alpha values known above 0,6 means that has met the requirements so that the composite reability value $x_{1}=0,804, x_{2}=0,904$ dan $Y=0,895$. That they have fulfilled reliability based on composite reability.

These results were obtained from significant tests. The hypothesis 1 variable halal tourism $x_{1}=0,804$ has a significant value $x_{1}=0,014$ smaller than 0.05 so that it looks significant because $x_{1}$ has a significant effect on the value of $Y$. The hypothesis 2 variable service quality $x_{2}=0,904$ has a significant value $x_{2}=0.001$ smaller than 0.05 so that it looks significant because $x_{2}$ has a significant effect on the value of $Y$. The hypothesis of 3 variable halal tourism and service quality from the ANOVA table with a significant level of 0,000 smaller than 0.005 so that it looks significant because $x_{1}$ and $x_{2}$ have a significant effect on the value of $Y$. Based on the results of the coefficient of determination located in the adjusted $\mathrm{R}$ Square table is 0.848 , which means 84.8 variable service quality and halal tourism together affect the brand image of hospitality services in Padang City

Indonesia with a large population and the majority of Islamic religion makes Indonesia one of the world's Islamic tourist destinations, so that the development of halal tourism is growing rapidly Wardi et al. (2018) says halal tourism is not only halal products, in the form of halal food and beverages without alcohol, still provide all tourist information without lying to tourists with false information. Halal tourism has a significant impact on the hospitality service brand image (H1). This is in line with the findings of Ismail et al. (2016) stated that the halal logo gives more value to the brand image of products in Malaysia. Availability of Islamic facilities in a tourist place makes it easy for Muslim tourists. As stated by Wardi et al., (2018). The availability of Islamic facilities and places of worship such as prayer rooms, makes it easy for Muslim tourists so that they prefer and enjoy holidays.

Service quality has a significant effect on hospitality service brand image (H2). Lee et al., (2018). Declaring service quality of a hotel gives more trust to the hotel. Hotels that have good service quality provide trust in hotels. Halal tourism and service quality together have a significant effect on Brand Image (H3). This benefits the world of Muslim tourism. By combining between quality service and halal tourism, Islamic hotels are created, where hotels applying Islamic rules to their respective hotels and Muslim tourists more comfortable to stay and enjoying the vacation. 


\section{Conclusions}

Based on the research we conducted found halal tourism has an effect of 0.783 or as large as $78.3 \%$ with a significant value of 0.014 so that it is smaller than the level of significance $(\alpha)$ of 0.050 towards the hospitality brand image in Padang City so that the decision is rejected and H1 is accepted. Based on the research we conducted found service quality had an effect of 0.215 or as large as $21.5 \%$ with a significant value of 0.001 so that it was smaller than the level of significance $(\alpha)$ of 0.050 towards the hospitality brand image in Padang City so that the decision was rejected and H1 was accepted. Based on the research we conducted found halal tourism and service quality had an effect of 208.105 with a significant value of 0.000 so that it was smaller than the level of significance $(\alpha)$ of 0.050 towards the hospitality brand image in Padang City so that the decision was rejected and H1 was accepted.

From the research that we have done, there are some things that need to be improved for hotel owners to become tourist destination hotels and support government programs as Islamic tourist attractions, among others, to provide wider places of worship, facilitate access from tourist attractions to hotels, for example by transportation directly. In the future, it is necessary to specifically make sharia hotels that accommodate all the needs of Muslim tourists, especially and can accommodate non-muslin tourists.

\section{References}

Abror, A., Wardi, Y., Trinanda, O., \& Patrisia, D. (2019). The impact of Halal tourism, customer engagement on satisfaction: moderating effect of religiosity. Asia Pacific Journal of Tourism Research, 24(7), pp. 633-643. doi:10.1080/10941665.2019.1611609

Al-Hamarneh, A. and Steiner, C. (2004). Islamic Tourism" - Re-Thinking the Strategies of Tourism Development in the Arab World After 9/11, Comparative Studies of South Asia, Africa and the Middle East, 24(1), Spring.

Al-Qaradawi, Y. (2013). The lawful and the prohibited in Islam: Shoruuk International. p. XXV

Alserhan, B. A. (2010). On Islamic branding: brands as good deeds. Journal of Islamic Marketing, 1 (2), $101-106$.

Arikunto, S., (2002). Prosedur Penelitian : Suatu Pendekatan Praktek, Jakarta; Rineka Cipta

Battour, M., Battor, M., \& Bhatti, M. A. (2014). Islamic attributes ofdestination: Construct development and measurement vali-dation, and their impact on tourist satisfaction. International Journal of Tourism Research,16(6), 556-564

Chen, C.-T., Cheng, C.-C., \& Hsu, F.-S. (2013). GRSERV scale: an effective tool for measuring consumer perceptions of service quality in green restaurants. Total Quality Management $\mathcal{E}$ Business Excellence, 26(3-4), 355-367. doi:10.1080/14783363.2013.832478

Cretu, A.E., \& Brodie, R.J. (2007). The influence of brand image and company reputation where manufacturers market to small firms: A customer value perspective. Industrial Marketing Management, 36(2), 230-240.

Dalimunthe, D.M.J., Fadli, \& Muda, I. (2016). The application of performance measurement system model using Malcolm Baldrige Model (MBM) to support Civil State Apparatus Law (ASN) number 5 of 2014 in Indonesia. International Journal of Applied Business and Economic Research. 14(11). 7397-7407.

El-Gohary, H. (2016). Halal tourism, is it really Halal? Tourism Management Perspectives, 19(Part B), 124-130. doi:10.1016/j. tmp.2015.12.013. Retrieved from http://www.sciencedirect. com/science/article/pii/S2211973615001038

Erlina, Saputra, A \& Muda, I. (2017). The Analysis of the Influencing Factors of Budget Absorption. International Journal of Economic Research. 14(12). 287-300.

Handoko, B., Sunaryo \& Muda, I. (2017). Difference Analysis of Consumer Perception of Motorcycle Product Quality. International Journal of Economic Research. 14(12). 363-379.

Hasan, A., Gusnardi \& Muda, I. (2017). Analysis of Taxpayers and Understanding Awareness Increase in Compliance with Taxpayers Individual Taxpayers. International Journal of Economic Research. 14(12). 75-90. 
Iniesta-Bonillo, M.A., Sanchez-Fernandez, R. \& Jimenez-Castillo, D. (2016). Sustainability, value, and satisfaction: Model testing and cross-validation in tourist destinations, Journal of Business Research, 69, (11), 5002-5007.

Ismail, W. R. B. W., Othman, M., Rahman, R. A., Kamarulzaman, N. H., \& Rahman, S. A. (2016). Halal Malaysia Logo or Brand: The Hidden Gap. Procedia Economics and Finance, 37, 254261.doi:10.1016/s2212-5671(16)30122-8

Kandampully, J., \& Suhartanto, D. (2003). The Role of Customer Satisfaction and Image in Gaining Customer Loyalty in the Hotel Industry. Journal of Hospitality $\mathcal{E}$ Leisure Marketing, 10(1-2), 3 25.doi:10.1300/j150v10n01_02

Kim, H.B. \& Kim, W.G (2005). The relationship between brand equity and firm's performance in luxury hotels and chain restaurants. Tourism Management, 26, 549-560.

Kotler, P. and Keller, K.L (2012), Marketing Management, Global Edition 14e, London: Pearson Education Limited 2012

Kozak, M. (2002). Comparative analysis of tourist motivations by nationality and destinations. Tourism Management, 23(3), 221-232

Laderlah, S.A., Rahman S.A., Awang, K., \& Man, Y.C (2011). A Study on Islamic Tourism: A Malaysian Experience. In 2nd International Conference on Humanities, Historical and Social Sciences IPEDR, vol. 17. Singapore: IACSIT Press.

Lado-Sestayo, Fernández-Castro (2018). The impact of tourist destination on hotel efficiency: A data envelopment analysis approach. European Journal of Operational

Lee, W.-H., \& Cheng, C.-C. (2018). Less is more: A new insight for measuring service quality of green hotels. International Journal of Hospitality Management, 68, 32-40. doi:10.1016/j.ijhm.2017.09.005

Liu, M. T., Wong, I. A., Tseng, T.-H., Chang, A. W.-Y., \& Phau, I. (2017). Applying consumer-based brand equity in luxury hotel branding. Journal of Business Research, 81, 192-202. doi:10.1016/j.jbusres.2017.06.014

Muda, I., (2017). The Effect of Supervisory Board Cross-Membership and Supervisory Board Members' Expertise to The Disclosure of Supervisory Board's Report: Empirical Evidence from Indonesia. European Research Studies Journal. XX(3A). 702-716.

Ramanathan, U., \& Ramanathan, R., (2013). Investigating the impact of resource capabilitieson customer loyalty: a structural equation approach for the UK hotels using onlineratings. J. Serv. Mark. 27 (5), 404-415

Situmorang, S.H, Rini, E.S \& Muda, I. (2017). Customer Experience, Net Emotional Value and Net Promoter Score on Muslim Middle-Class Women in Medan. International Journal of Economic Research. 14(20). 269-283

Sparks \& Westgate, (2002). Broad-based and targeted sponsorship strategies in Canadian women's ice-hockey.International Journal of Sports Marketing and Sponsorship, 4(1), 59-84.

Sugiyono, (2012), Metode Penelitian Kuantitatif Kualitatif dan RED. Bandung: Alfabeta.

Surachman, (2008), Dasar-Dasar Manajemen Merek (Alat Pemasaran Untuk Memenangkan Persaingan). Malang: Bayumedia Publishing.

Ukessays. (2014). Islamic Attributes Of Destination On Tourists Motivation. Retrieved from http://www. ukessays. com/essays/tourism/islamic-attributes-of-destination-on tour-ists motivation-tourism-essay.php.

Wardi, Y., Abror, A., \& Trinanda, O. (2018). Halal tourism: antecedent of tourist's satisfaction and word of mouth (WOM). Asia Pacific Journal of Tourism Research, 23(5), pp. 463-472. doi:10.1080/10941665.2018.1466816

Wreksono, A. (2016). 12 Indonesian entities vie for World Halal Tourism Award. The Jakarta Post. Retrieved from http:// www.thejakartapost.com/travel/2016/10/12/12-indonesianentities-vie-forworld-halal-tourism-award.html

Yoo, B., Donthu, N., \& Lee, S. (2000). An examination of selected marketing mix elements and brand equity. Journal of the Academy of Marketing Science, 28(2), 195-211. 